\title{
Board Gender Diversity and Corporate Sustainability Performance: Mediating Role of Enterprise Risk Management
}

\author{
A. N. M. Asaduzzaman FAKIR ${ }^{1}$, Ruzita JUSOH ${ }^{2}$
}

Received: March 18, 2020 Revised: April 04, 2020 Accepted: May 01, 2020

\begin{abstract}
The objective of this paper is to explore how board gender diversity affects corporate sustainability performance. Therefore, this paper examines the direct association between board gender diversity with corporate sustainability performance and the mediation effect of enterprise risk management (ERM) on this association. The study employed a cross-sectional survey method. Data were collected from annual reports, websites, and through the questionnaires that were distributed to Chief Financial Officers (CFOs) of all the listed companies of Dhaka Stock Exchange, Bangladesh. The partial least square technique of Structural Equation Modelling (SEM) approach was employed for data analysis. The result did not find support for the direct association between board gender diversity and sustainability performance in Bangladesh context. This implies that contextual factors, such as, male-dominant board, appointment of female directors based on family ties, lack of education and expertise etc. may discount gender diversity direct influence on sustainability performance. However, the study finds strong support for the mediating role of ERM use within the corporate structure. Further analysis of indirect effect suggests that ERM use mediates the relationship of board gender diversity and sustainability performance in full. This implies that in the Bangladesh context effective use of ERM is highly recommended.
\end{abstract}

Keywords : Women Director, Board Gender Diversity, Enterprise Risk Management, Corporate Sustainability Performance

JEL Classification Code: G32, G34, M14, Q56

\section{Introduction}

Sustainability is a standout amongst the most vital management paradigms that key business leaders must react to today in search of competitive success (Bansal, 2005). Bansal (2005, p. 48), a leading sustainability author, argues that almost inevitably companies that do not react to sustainability will face extinction. Likewise, some say that the capability to incorporate sustainability into corporate

${ }^{1}$ First Author. Assistant Professor, Department of Accounting \& Information Systems, Faculty of Business Studies, Jagannath University, Dhaka, Bangladesh.

Email: asaduzzamanfakir@gmail.com

${ }^{2}$ Corresponding Author. Professor, Department of Accounting, Faculty of Business and Accountancy, University of Malaya, Malaysia [Postal Address: 50603 Kuala Lumpur, Malaysia]

Email: geee@um.edu.my

(c) Copyright: The Author(s)

This is an Open Access article distributed under the terms of the Creative Commons Attribution Non-Commercial License (http://Creativecommons.org/licenses/by-nc/4.0/) which permits unrestricted noncommercial use, distribution, and reproduction in any medium, provided the original work is properly cited. strategy and stakeholder engagement will determine which businesses will grow in the 21 st century and which businesses will fail (e.g., Andriosopoulos, 2016; Napitupulu, Primiana, Nidar, Effendy, \& Puspitasari, 2020). Considering these dauntless claims, it is obvious that it is important to know how businesses adapt to sustainability.

Research has so far focused on understanding why businesses are committed to sustainability in particular. However, Sharma and Henriques (2005) urge more research on the internal drivers, as researching these drivers will demonstrate how organizations grow and begin to understand sustainability. Boards of directors are the most powerful internal drivers and are the leading corporate decision-making body (Rao \& Tilt, 2016). As such, they exercise tremendous power and responsibility in supervising companies, and, thus, have a significant impact on the company strategy, which, subsequently, affects their performance (Fama \& Jensen, 1983). It is therefore of critical importance to determine the correct composition of board members. A prominent suggestion for improving the efficiency of the board concerns gender diversity. For example, PricewaterhouseCoopers's (PwC) Annual Corporate Directors Survey 2018 reports that 
directors pay heed to gender diversity and that $46 \%$ of the directors surveyed ranked gender diversity as being the most important board attribute for an effective board. The survey also reports that this figure was highest in 2018 since the survey started asking such questions in 2012 (see Figure 1).

Regarding sustainability performance for modern corporations, gender diversity on the boards has been, and will continue to be, a focus amongst other governance issues in the next few years (Vanguard, 2017). For example, the State Street Global Advisors (SSGA) voted against the directors of 581 firms worldwide with no female members on the board (SSGA, 2018). Female representation in corporate decision-making is also of vibrant importance to policymakers. Norway, for example, enacted quota laws in 2006 requiring 40 percent women's representation on the board for government-owned corporations.

In October 2018, California passed a similar women's quota law for company boards with deadlines in 2021. One reason for this increasing pressure is that gender diversity has been promoted as a way of boosting organizational interest and efficiency by instilling new insights, new knowledge, and different points of view in boards (Carter, Simkins, \& Simpson, 2003). New ideas and new ways of thinking at the board level are pretty important to address the sustainability challenge. Moreover, sustainability performance requires sustainable investor relationship and proper risk management (Yilmaz \& Flouris, 2010) while board gender diversity improves the relationship with investors and improves strategy or risk oversight (PwC, 2018). Therefore, it remains an interesting point to study the interaction between board gender diversity and corporate sustainability performance.

However, no global consensus has been achieved concerning under which conditions board gender diversity will have a significant impact on sustainability performance. Previous studies on this relationship have produced mixed results (Harjoto, Laksmana, \& Lee, 2015; McGuinness, Vieito, \& Wang, 2017; Velte, Jones, \& Jones, 2016). Consequently, it can fairly be argued that board attributes can implicitly affect firm sustainability performance by emphasizing certain variables, such as enterprise risk management (ERM). The Committee of Sponsoring
Organizations of the Treadway Commission (COSO) ERM framework clearly made the board of directors accountable for effective ERM use and it is also evident that ERM, in turn, can lead to CSP (Gordon, Loeb, \& Tseng, 2009; Yilmaz $\&$ Flouris, 2010). This premise reinforces the point that the Board of Directors rarely directly impacts sustainability performance, but can do so implicitly through a series of causes and effects. This study is therefore driven to justify these claims by exploring the role of ERM as the mediator in the relationship between board gender diversity and corporate sustainability performance.

Therefore, the primary objective of this paper is to explore how board gender diversity affects sustainability performance. The study aims to examine the direct relationship as well as the indirect relationship via ERM use. In both academic and business fields, it seems particularly important to answer the above-mentioned question.

The paper is broken down into five parts. An analysis of the theoretical framework will be presented after this introduction. The third section contains information on the model estimation, variables, sample, and methods used. The fourth section interprets the findings of the empirical analysis, while the study is summarized and concluded in the final section.

\section{Literature Review and Theoretical Framework}

\subsection{Board Gender Diversity and CSP}

Scholars have explained several reasons for why women on the board should have a positive impact on CSP. First, it is argued that female directors will increase investor trust by improving the transparency, openness, and moral obligation in the boardroom (Arfken, Bellar, \& Helms, 2004; Tahir, Rahman, \& Masri, 2020). For example, Tahir et al. (2020) investigate factors that determine dividend payout policy using 336 non-financial year observations for the period 2005 to 2016 in Malaysia and find that board traits measured by board diversity have a positive effect on payout policy

Gender diversity grows in importance

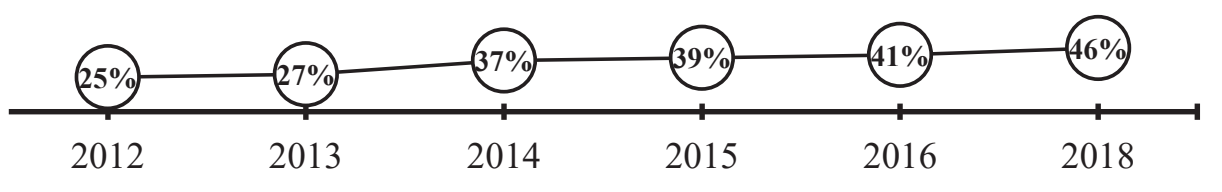

$-0-\%$ responding that gender diversity is very important

Source: PwC (2018), Annual Corporate Directors Survey, October 2018

Figure 1: Gender diversity growth over the years 
that signals good news for investors. Secondly, disparities in the predominant context regarding the sociology and training of female directors may lead to an improved social response orientation (Wang \& Coffey, 1992; Williams, 2003).

Women directors are therefore more open to CSR, in general, and philanthropic programmes, in particular (Williams, 2003). Thirdly, increasing the number of female board members may enable efficient business management by addressing broader customer demand (Daily \& Dalton, 2003), which allows businesses to pursue CSR measures that boost the proactive attitude of companies in terms of sustainability. In addition to that, corporate governance and economic efficiency literature show that gender diversity results in better management decisions and economic performance (Campbell \& Mínguez-Vera, 2008; Rao \& Tilt, 2016; Sultana, Zulkifli, \& Zainal, 2018). Based on the discussion outlined above, the study hypothesizes the following relationship:

Hypothesis 1: Board gender diversity positively affects sustainability performance

\subsection{ERM Use as a Mediator between Board Gender Diversity and CSP}

The study conceptualizes ERM as the device designed to manage risks and opportunities within its risk appetite extended throughout the company at all levels and divisions, which can provide reasonable assurance to the management and board of directors of an organization. Therefore, the definition provided by the Enterprise Risk ManagementIntegrated Framework (2004) is adopted as below:

"Enterprise risk management is a process, effected by an entity's board of directors, management and other personnel, applied in strategy setting and across the enterprise, designed to identify potential events that may affect the entity, and manage risk to be within its risk appetite, to provide reasonable assurance regarding the achievement of entity objectives."

It is already mentioned that empirical support for how board gender diversity affects corporate sustainability performance through ERM use is lacking. However, several social-psychological explanations for indirect linkage can be found. Under the traditional legal model of the corporation, the board of directors has been held responsible for the management of the business operations. However, it is unrealistic to think that the board will manage the day-to-day operations. Therefore, it is customary that the board appoints managers to do the job on their behalf, and that the board of directors oversee the management functions (Eisenberg, 1997). Managing risk is fundamental to the key responsibility of managers. Instead of looking from a silo-based viewpoint at risk management, the cultural shift to a holistic perspective of risk management is commonly referred to as ERM. Besides, the generic claim that companies can boost their efficiency by applying the principle of ERM is increasingly accepted. ERM use reduces information asymmetry among different business units (Brown \& Hillegeist, 2007) and enhances investors' confidence (Ai, Brockett, Cooper, \& Golden, 2012), and, thereafter, positively influences company's value and performance (Gordon et al., 2009; Yilmaz \& Flouris, 2010). Therefore, it can reasonably be argued that ERM can lead to CSP.

Notwithstanding that ERM affects CSP, it is the board of directors who determine the effective use of ERM in an organization. The COSO ERM framework clearly made the board of directors responsible for effective ERM use (COSO, 2004). In a similar vein, it is reasonable to argue that gender diversity among directors may lead to improved ERM practices that allow the achievement of better sustainability outcomes for several reasons. More female board members can render important credibility to future and existing investors. A larger number of women directors may enforce the implementation of certain guidelines, such as ERM, by increasing transparency and moral duty in the board room (Arfken et al., 2004). Women directors are more stakeholder-oriented and more open to social responsiveness (Daily \& Dalton, 2003; Williams, 2003). Hence, female board members may push the other board members to ensure the effective use of ERM.

Several studies have shown that ERM plays the role of a mediator. For example, Talke, Salomo, and Rost (2010) find that ERM use mediates the link between the executives' role and the performance of German firms. From the Malaysian context, Soltanizadeh et al. (2016) illustrate how ERM mediates the relationship between business strategy and performance. In a similar vein, Parker and Ameen (2017) use 'proactive risk management' as a mediator in the context of South Africa.

Thus, this study assumes that board gender diversity will directly affect ERM use, which, in turn, will affect sustainability performance. Consequently, the following hypothesis is proposed:

Hypothesis 2: Board gender diversity positively affects sustainability performance by means of ERM use.

\subsection{Theoretical Foundation}

This study proposes that board gender diversity (as firm resources) may influence corporate sustainability. This can be underpinned by the resource dependence theory (RDT). Considering corporate sustainability performance where expertise and adaptability in environmental changes are required, board gender diversity can benefit in acquiring 
critical resources from the environment (Provan, 1980). Women directors may bring linkage that elicits useful information, obtain commitments of support from the external environment, and gain legitimacy for doing business in the society (Hillman, Shropshire, \& Cannella, 2007; Pfeffer \& Salancik, 1978). Female directors are more proactive towards social responsiveness in comparison to their male counterparts (Wang \& Coffey, 1992; Williams, 2003). Therefore, RDT may better explain the board gender diversity role on corporate sustainability performance, which includes environmental, social goals along with financial goals. In fact, RDT can also justify organizational behaviour with social recognition as a further motive, rather than a mere focus on financial performance (Daily \& Dalton, 2003).

The indirect path of the study can be viewed from the contingency lens, or, more specifically, fit, as the mediation perspective of the contingency theory lens. The contingency theory contends that high corporate output emerges from balancing the structure of a company with its internal and external contingencies. In other words, the contingency theory argues that the influence of any business design on its performance is specific to its organizational context. The fit between organizational processes is a must for any such relationship to be established. Contingency dictates the structure of the organization, and, fitting between the organizational cycle leads to higher performance, while a misfit leads to lower performance.

The contingency approach integrates the decision-based theory and system theory to define an open system with an "ifthen" relationship between two or more defined business units (Lawrence \& Lorsch, 1967). The key concept in a contingent proposition is 'fit', which can be tested to determine whether or not an organization has achieved a fit for a particular organizational structure or process (Baron \& Kenny, 1986). According to Baron and Kenny (1986), mediators explain how and why a relationship between two other variables is established (typically well defined) and are sometimes referred to as intermediary variables as they often define the mechanism by which an effect occurs. The contingency theory also states that a fit between organizational processes is required, which, in turn, determines increased firm performance. Therefore, consistent with fit as a mediation perspective of the contingency theory, the causal chain can be established where board gender diversity affects ERM use, and, in turn, ERM use affects corporate sustainability performance.

\section{Methodology}

\subsection{Sample}

The study employed a cross-sectional survey method. Data were collected in two steps. In the first step, to obtain data on ERM use and CSP, structured questionnaires were distributed to the Chief Financial Officers (CFOs) employed in publicly-listed firms on the Dhaka Stock Exchange (DSE), Bangladesh. In the second step, after receiving and screening the returned questionnaires, the responding companies' official websites and their latest annual reports were examined to obtain data on board gender diversity and control variables (firm size, industry type, board size, CEO tenure, and slack resources).

This study selected DSE listed companies as the unit of analysis, as these organizations, for each sector in Bangladesh, are regarded as the most influential and dominant group of companies. According to DSE, as of May 2, 2017, only 298 companies were listed. As the population is limited, and, as a consequence of the multi-industry survey, as mentioned above, the whole population was chosen as a test sample to provide an accurate, more robust and rigorous analysis.

A pre-testing procedure was carried out in three stages before final delivery of the questionnaire. The face validity and content validity of the questionnaire were performed by a panel of experts. This was followed by a pilot study on 32 CFOs within the DSE. All the assessments of reliability and validity statistics were found to be acceptable, thus legitimizing the distribution of questionnaires for the actual data collection.

CFOs were considered as the targeted respondents because they are considered to be the most knowledgeable about CSP and ERM implementation due to their direct involvement in the administrative process and procedures of the company. Following two mailings and a follow-up phone call, a total of 184 responses were received from which 166 (62.41 percent) were used to analyse data.

\subsection{Respondents' Profile}

The profile of the respondents is summarized in Table 1, which shows that there were more male (92.2\%) respondents compared to female $(7.8 \%)$. This percentage of male and females is representative of the current number of managers in Bangladeshi companies in that most of them are male. With respect to education level, most (95.8\%) of the respondents held postgraduate degrees, while 3.6\% of the respondents held undergraduate degrees. Moreover, $99.4 \%$ of the respondents had at least an accounting or other business professional qualification. This indicates that the respondents are highly educated, which is reflective of the positions held by them. Age-wise, more than half $(51.8 \%)$ of the respondents were between 50 and 59 years old. The age group of 40-49 years old was next in terms of proportion with 41 percent of the total respondents while the age group 60 years and above was the least with $1.8 \%$. An examination of the respondents' years of employment with their present company indicates that almost half (44\%) of the 
Table 1: Respondents' demographic profile

\begin{tabular}{|c|c|c|c|}
\hline Profile & Category & Frequency & Percent \\
\hline \multirow[t]{3}{*}{ Gender } & Male & 153 & 92.2 \\
\hline & Female & 13 & 7.8 \\
\hline & Total & 166 & 100.0 \\
\hline \multirow[t]{5}{*}{ Education } & Diploma & 1 & 0.6 \\
\hline & Degree & 6 & 3.6 \\
\hline & Masters & 158 & 95.2 \\
\hline & PhD & 1 & 0.6 \\
\hline & Total & 166 & 100.0 \\
\hline \multirow{4}{*}{$\begin{array}{l}\text { Professional } \\
\text { Qualification }\end{array}$} & No Degree & 1 & 0.6 \\
\hline & CA/CMA & 154 & 92.8 \\
\hline & $\begin{array}{l}\text { Other (CS, CFA } \\
\text { etc.) }\end{array}$ & 11 & 6.6 \\
\hline & Total & 166 & 100.0 \\
\hline \multirow[t]{5}{*}{ Age } & Below 40 & 9 & 5.4 \\
\hline & $40-49$ & 68 & 41.0 \\
\hline & $50-59$ & 86 & 51.8 \\
\hline & 60 and above & 3 & 1.8 \\
\hline & Total & 166 & 100.0 \\
\hline \multirow[t]{4}{*}{ Experience } & $\begin{array}{l}\text { Less than } 3 \\
\text { years }\end{array}$ & 60 & 36.1 \\
\hline & $3-5$ years & 73 & 44.0 \\
\hline & Over 5 years & 33 & 19.9 \\
\hline & Total & 166 & 100.0 \\
\hline
\end{tabular}

respondents had 3-5 years of experience in their companies. A large proportion (64.9\%) of the respondents had over three years of experience. These figures demonstrate that the respondents are familiar with the company's processes and business environment. Hence, they have the relevant knowledge to answer the questionnaire, which, later, results in a more reliable analysis.

\subsection{Measurement of Variables}

\subsubsection{Corporate Sustainability Performance (CSP)}

This study conceptualizes CSP as a higher-order formative construct that includes four dimensions of sustainability, i.e., financial, economic, social, and governance. As previously argued, these four dimensions are an integral part of sustainability and they determine sustainability, and overlooking any one dimension will result in diminutively defined CSP with respect to the conceptualization of this study. However, these dimensions are measured through reflective indicators constituting a first-order reflective construct adapted from previous studies (Rahdari \& Rostamy, 2015; Torugsa, O'Donohue, \& Hecker, 2012). This research favoured self-assessed perpetual performance measures for financial, social, environmental, and governance performance to measure the 'CSP' variable over objective measures, because key informants (for example, CFOs) seldom expect numbered objective performance data to be provided in the instrument. Furthermore, this approach of perceptual measurement of performance is well established in extant literature arguing that perceived measures could be a sensible alternative for objective performance indicators (Dess \& Robinson, 1984). Therefore, consistent with the literature, this study asks CFOs to assess the performance of their firms on the basis of specific factors using a 7-point Likert-type scale with responses ranging from 'significantly above average' (7) to 'significantly below average' (1).

\subsubsection{Enterprise Risk Management (ERM)}

According to the COSO (2004), ERM comprises eight interrelated modules extracted from the management framework that are essential for operating and implementing the device. ERM is not simply a sequential mechanism in which one variable only influences the next one. It is a multidirectional, iterative process that can and does affect almost any variable on another. The study aims to assess the effective use of ERM in a particular organization setting. For this, these eight components can be proxied to assume whether or not an entity is using ERM effectively to manage its risk holistically (COSO, 2004 p-5).

Accordingly, consistent with the previous studies, this study uses an instrument consisting of a total of eight components of the ERM framework (Moeller, 2007). CFOs were asked to rate the extent to which each measure was used by their organization on the eight components using a 7-point Likert scale ranging from 7 (to a very large extent) to 1 (not at all).

\subsubsection{Independent and Control Variables}

The study measures board gender diversity as a ratio of female members to total members on the board (De Cabo, Gimeno, \& Nieto, 2012; Sila, Gonzalez, \& Hagendorff, 2016). In addition to that, consistent with other organizational studies, firm size, industry type, board size, CEO tenure, and slack resources were treated as control variables for this study (Artiach, Lee, Nelson, \& Walker, 2010; Chih, Chih, \& Chen, 2010; Lourenço \& Branco, 2013). Table 2 shows the measurement of the control variables. 
Table 2: Independent and Control Variables Measurement

\begin{tabular}{|l|l|l|}
\hline \multicolumn{1}{|c|}{ Variable } & \multicolumn{1}{c|}{ Measurement } & \multicolumn{1}{c|}{ Sources } \\
\hline Board Gender Diversity & Ratio of female members to total members on the board & De Cabo et al. (2012), Sila et al. (2016) \\
\hline Firm Size & Total Assets of the Firm & Artiach et al. (2010); Chih et al. (2010) \\
\hline Industry & $\begin{array}{l}\text { Set equal to 1 if the firm belongs to an environmentally } \\
\text { sensitive industry, 0 otherwise }\end{array}$ & Artiach et al. (2010) \\
\hline Board Size & Total number of directors on the board & Huang and Wang (2015) \\
\hline CEO Tenure & Number of years since the CEO was appointed & Simsek (2007) \\
\hline Slack Resources & Cash on hand at the end of the year & George (2005) \\
\hline
\end{tabular}

\section{Results}

\subsection{Assessment of Measurement Model}

Similar to other SEM techniques, PLS typically employs a two-step process (Chin, Marcolin, \& Newsted, 2003; Hair Jr, Hult, Ringle, \& Sarstedt, 2017). At the beginning, the measurement model is evaluated along the same lines as the factor analysis and unidimensionality tests. The structural model is evaluated in the next phase to provide a path coefficient that demonstrates how each variable is associated. Unlike covariance-based SEMs, the significance of PLS-SEM Path Coefficients can only be estimated using a Bootstrapping or Jackknifing re-sampling method. In this study, the Bootstrapping technique was used for data analysis.

\subsubsection{Assessment of Reflective and Formative Construct}

The study conceptualizes its independent variable (board gender diversity) as the directly observed exogenous construct in the SEM model. Board gender diversity (DirWom) is used as a single item reflective construct in the SMART PLS model because of the program's constraint in using directly observed variables.

As shown in Table 3, the descriptive statistics for the board gender diversity (exogenous construct) show that the average number of board members in each firm is 10.08 while the average number of female directors is 1.72 with a standard deviation of 1.919 that ranges from 0 to 12. Notably, on each board, 17.06 percent of members are female directors. For ERM use and CSP constructs, they are not directly observed, and, thus, conceptualized as latent variables. Assessing latent variables includes construct reliability, convergent validity, and discriminant validity.

Construct reliability refers to the internal coherence of the scale for measuring the latent variable, or, in other words, the unidimensionality of a construct (Garver \& Mentzer, 1999). (Garver \& Mentzer, 1999). For construct reliability, a generally accepted rule of thumb is to endorse items with a loading value equal to or over 0.70 (Hair Jr et al., 2017). According to Hair Jretal.(2017), the greater the factor loadings of the item, the stronger the proof of unidimensionality. Two other measures of construct reliability are the Cronbach's alpha and composite reliability score where the cut-off point is 0.70 (Chin et al., 2003). Table 4 shows that the factor loadings, Cronbach's alpha, and composite reliability score are all above 0.70 . Convergent validity is defined as the degree to which theoretically related constructs are in fact interrelated, while discriminant validity is defined as the degree to which theoretically unrelated constructs are not interrelated. (Hair Jr et al., 2017). Convergence is obtained if an average variance extracted between the constructs or AVE is greater than 0.5 (Chin et al., 2003). AVE measures the shared variance between a construct and its indicators.

According to Table 4, the minimum AVEs is reported as 0.664 for CESP, which also achieved the desired score. In order to test discriminant validity, this study followed Fornell and Larcker's suggestion (1981). According to Fornell and Larcker (1981), the AVE square root ought to be greater than the construct correlations. Using this criterion, the results in Table 4 show adequate discriminant validity for all constructs.

To assess the formative construct, examination of the weight and multicollinearity is recommended (Hair Jr et al., 2017). Table 5 reveals that all the dimensions of CSP are significantly associated with the construct and that this significance is not biased by multicollinearity.

\subsubsection{Common Method Bias}

In self-reported studies, common method bias is one of the major issues regarding the validity of the measurements. Usually, when all the constructs of a study are measured through the key informant approach, a common method bias test is recommended. However, in this study, only the mediating and dependent constructs were measured through self-reporting while the independent construct was measured through data collected from the secondary source. Therefore, the study assumes that no threat to common method bias 
Table 3: Descriptive Statistics and Reliability Statistics for Reflective Constructs

\begin{tabular}{|c|c|c|c|c|c|c|}
\hline & Items & Mean & Std. Dev & Factor Loading & Cronbach's Alpha & Composite Reliability \\
\hline Board Gender Diversity & DirWom & 0.211 & 0.281 & & & \\
\hline \multirow{8}{*}{$\begin{array}{l}\text { Enterprise Risk } \\
\text { Management }\end{array}$} & erm1 & 4.91 & 1.357 & 0.853 & \multirow{8}{*}{0.949} & \multirow{8}{*}{0.957} \\
\hline & erm2 & 4.98 & 1.326 & 0.894 & & \\
\hline & erm3 & 4.87 & 1.305 & 0.889 & & \\
\hline & erm4 & 4.93 & 1.342 & 0.877 & & \\
\hline & erm5 & 4.90 & 1.345 & 0.844 & & \\
\hline & erm6 & 5.01 & 1.277 & 0.853 & & \\
\hline & erm7 & 4.84 & 1.403 & 0.801 & & \\
\hline & erm8 & 5.02 & 1.291 & 0.851 & & \\
\hline \multirow{3}{*}{$\begin{array}{l}\text { Corporate Financial } \\
\text { Sustainability } \\
\text { Performance }\end{array}$} & fs 1 & 4.74 & 1.505 & 0.898 & \multirow{3}{*}{0.901} & \multirow{3}{*}{0.938} \\
\hline & fs2 & 4.83 & 1.421 & 0.928 & & \\
\hline & fs3 & 4.89 & 1.339 & 0.914 & & \\
\hline \multirow{7}{*}{$\begin{array}{l}\text { Corporate } \\
\text { Environmental } \\
\text { Sustainability } \\
\text { Performance }\end{array}$} & es1 & 4.17 & 1.579 & 0.856 & \multirow{7}{*}{0.915} & \multirow{7}{*}{0.932} \\
\hline & es2 & 4.52 & 1.679 & 0.800 & & \\
\hline & es3 & 4.47 & 1.508 & 0.838 & & \\
\hline & es4 & 4.69 & 1.590 & 0.803 & & \\
\hline & es5 & 4.63 & 1.390 & 0.864 & & \\
\hline & es6 & 4.81 & 1.451 & 0.792 & & \\
\hline & es7 & 4.57 & 1.495 & 0.744 & & \\
\hline \multirow{5}{*}{$\begin{array}{l}\text { Corporate Social } \\
\text { Sustainability } \\
\text { Performance }\end{array}$} & ss1 & 4.90 & 1.381 & 0.806 & \multirow{5}{*}{0.903} & \multirow{5}{*}{0.929} \\
\hline & ss2 & 4.78 & 1.427 & 0.898 & & \\
\hline & ss3 & 4.57 & 1.368 & 0.782 & & \\
\hline & ss5 & 4.64 & 1.380 & 0.893 & & \\
\hline & ss6 & 4.60 & 1.353 & 0.865 & & \\
\hline \multirow{4}{*}{$\begin{array}{l}\text { Corporate Governance } \\
\text { Sustainability } \\
\text { Performance }\end{array}$} & gs1 & 4.93 & 1.234 & 0.904 & \multirow{4}{*}{0.909} & \multirow{4}{*}{0.936} \\
\hline & gs2 & 4.77 & 1.310 & 0.859 & & \\
\hline & gs4 & 4.81 & 1.344 & 0.879 & & \\
\hline & gs5 & 4.79 & 1.306 & 0.904 & & \\
\hline
\end{tabular}

Table 4: Assessment of AVE and Fornell Larker Criteria for reflective constructs

\begin{tabular}{|l|c|c|c|c|c|c|}
\hline & AVE & ERM & CESP & CFSP & CGSP & CSSP \\
\hline ERM & 0.736 & $\mathbf{0 . 8 5 8}$ & & & & \\
\hline CESP & 0.664 & 0.653 & $\mathbf{0 . 8 1 5}$ & & & \\
\hline CFSP & 0.835 & 0.529 & 0.509 & $\mathbf{0 . 9 1 4}$ & & \\
\hline CGSP & 0.786 & 0.710 & 0.567 & 0.610 & $\mathbf{0 . 8 8 7}$ & \\
\hline CSSP & 0.723 & 0.601 & 0.629 & 0.691 & 0.630 & $\mathbf{0 . 8 5 0}$ \\
\hline
\end{tabular}

*Off diagonal values represents the square root of AVE score of respective construct; CFSP= Corporate Financial Sustainability Performance, CESP= Corporate Environmental Sustainability Performance, CSSP= Corporate Social Sustainability Performance, CGSP $=$ Corporate Governance Sustainability Performance. 
Table 5: Assessing path weight and significance for the formative construct CSP

\begin{tabular}{|l|l|c|c|c|c|c|}
\hline $\begin{array}{l}\text { Second Order } \\
\text { Construct }\end{array}$ & \multicolumn{1}{|c|}{ First Order Construct } & Weight & \multirow{2}{*}{$\begin{array}{c}\text { Standard } \\
\text { Error }\end{array}$} & \multirow{2}{*}{ T Statistics } & \multicolumn{2}{|c|}{ Collinearity Statistics } \\
\cline { 5 - 8 } & & & & Tolerance & VIF \\
\hline \multirow{2}{*}{$\begin{array}{l}\text { Corporate } \\
\text { Sustainability }\end{array}$} & Environmental Sustainability (CESP) & 0.463 & 0.018 & $24.618^{*}$ & 0.568 & $1.761^{* *}$ \\
\cline { 2 - 7 } $\begin{array}{l}\text { Performance } \\
\text { (CSP) }\end{array}$ & Financial Sustainability (CFSP) & 0.237 & 0.017 & $13.631^{*}$ & 0.477 & $2.098^{* *}$ \\
\cline { 2 - 7 } & Governance Sustainability (CGSP) & 0.203 & 0.015 & $12.997^{*}$ & 0.517 & $1.934^{* *}$ \\
\cline { 2 - 7 } & Social Sustainability (CSSP) & 0.272 & 0.017 & $15.819^{*}$ & 0.397 & $2.517^{* *}$ \\
\hline
\end{tabular}

* Significant at $p<0.01 ;{ }^{* *}$ No multicollinearity is detected

Table 6: Summary of Hypotheses and their Test Statistics for Direct Effects

\begin{tabular}{|c|c|c|c|c|c|c|c|c|}
\hline No & Hypothesis & Path & Beta Value & Sample Mean & Std. Error & T Statistics & $\mathbf{R}^{2}$ & $f^{2}$ \\
\hline 1 & $\mathrm{H} 1$ & DirWom-> CSP & 0.053 & 0.049 & 0.053 & 1.013 & 0.564 & 0.041 \\
\hline 2 & Cont. & FirmSize-> CSP & 0.005 & 0.316 & 0.065 & 0.121 & \multirow{5}{*}{0.588} & \\
\hline 3 & Cont. & Industry-> CSP & 0.129 & 0.277 & 0.075 & $2.441^{*}$ & & \\
\hline 4 & Cont. & BODSize-> CSP & 0.132 & 0.131 & 0.071 & 1.867 & & \\
\hline 5 & Cont. & CEOtenure-> CSP & 0.047 & 0.047 & 0.049 & 0.962 & & \\
\hline 6 & Cont. & Slack-> CSP & 0.167 & 0.166 & 0.098 & 1.710 & & \\
\hline
\end{tabular}

Cont. $=$ Control Variable; DirWom $=$ board gender diversity; ${ }^{*} p<0.01$

exists. Moreover, for the constructs using the key informant approach, during the development stage of the instrument various efforts were made to eliminate any bias, such as altering and modifying the item wording to find a more procedural wording that can avoid social desirability bias.

However, considering the fact that the inherent common method variance cannot be eliminated entirely, the study carried out a single-factor test (Harman, 1976) for all the constructs measured through self-reporting. Harman's singlefactor test is considered to be the most effective method to detect common method bias (Podsakoff, MacKenzie, Lee, \& Podsakoff, 2003). If the total variance for a single factor is less than 50 per cent, it suggests that common method bias does not affect the data. To obtain the total variance of the single factor, exploratory factor analysis (EFA) was carried out (Harman, 1976; Podsakoff et al., 2003). The results of this test demonstrated that the first extracted factor accounted for by only 47.44 percent of the total variance of 72.67 percent, which is acceptable (Harman, 1976; Podsakoff et al., 2003).

\subsection{Assessment of Structural Model (Direct Effect)}

The structural model in PLS is primarily assessed by extracting the estimated path coefficients and the $\mathrm{R}^{2}$ values. The path coefficient indicates the strength of the associations between the predictors and the dependent variables (Chin et al., 2003). The statistical significance of a path is used as a criterion for accepting or denying a hypothesized relationship. Adopting the recommendations of Hair Jr et al. (2017), the bootstrap re-sampling technique under SMARTPLS V2.0 M3 (Ringle, Wende, \& Will, 2005) was used to generate 5000 re-samples, which determines the estimated path coefficient and standard errors. Table 6 shows the direct effect hypotheses and corresponding test statistics, such as beta value or standardized path coefficients $(\beta)$, standard error, consequential t-statistics, $\mathrm{R}^{2}$ values, and Effect Size Determinants $\left(\mathrm{f}^{2}\right)$.

Table 6 signifies that the direct relationship between board gender diversity and CSP is insignificant $(\beta=0.053$, $\mathrm{t}=1.139$ ). Therefore, hypothesis 1 is not supported. Apart from the board gender diversity, control variables, such as firm size, industry, board size, CEO tenure, and cash at hand (slack), were also tested to check their significance on CSP. In respect of the control effects, the study found that only the effect of industry on CSP is significant at the $95 \%$ confidence interval while other control variables have no significant effect on CSP. The model is further assessed by its $\mathrm{R}^{2}$ and effect size $(f 2)$. The $\mathrm{R}^{2}$ value tests the predictive power of the dependent variables (Chin et al., 2003). However, effect sizes $(f 2)$ are independent of sample size and test the practical significance in terms of the magnitude. To measure the effect size, the Cohen (1988) approach is used in this process. According to Cohen (1988), changes in $\mathrm{R}^{2}$ values are examined by omitting exogenous constructs and looking at the impact on the endogenous constructs. The 
value of the $\mathrm{R}^{2}$ score for board gender diversity explains 56.4 percent variance in CSP, which indicates a moderate model (Hair Jr et al., 2017). After incorporating the control effects, $\mathrm{R}^{2}$ increases to 58.8 percent, which confirms that the model of this study provides a medium effect of board gender diversity on CSP (Cohen, 1988).

\subsection{Assessment of Mediation (Indirect) Effect}

In order to establish the criteria for mediation, as well as various forms of mediation and non-mediation, this study used the flowchart and step-by-step model developed by Zhao, Lynch, and Chen (2010). Zhao et al. (2010) argue that the existence of a statistically significant direct effect implies possible partial mediation, which can be either called complementary mediation (positive) or competitive mediation (negative). On the other hand, when the direct effect is found to be insignificant, full mediation is established. To test for the mediation/indirect effect of ERM on the relationship between board gender diversity and CSP, the bootstrapping procedure (Preacher and Hayes, 2008) was used.

The analysis of the indirect effect is done in two steps. The mediating variable ERM use is checked through bootstrapping the model using 5000 resamples with a $95 \%$ confidence interval on the indirect effect of board gender diversity on CSP. The results show that the $95 \%$ confidence interval does not straddle zero for the ERM use $(\mathrm{LL}=0.125$, $\mathrm{UL}=0.312)$. Hence, the indirect effect $\mathrm{a} \times \mathrm{b}(\beta=0.195$, $\mathrm{t}$-value 4.112) is significant, which, in turn, leads to establish the mediation effect of ERM use. Since the direct effect of board gender diversity on CSP is not significant $(\beta=-0.192$ and t-value 0.658), a full mediation is established (Hayes, 2017; Zhao et al., 2010). Therefore, H2 (ERM use mediates the relationship between board gender diversity and CSP) is supported.

\section{Discussion}

The study finds insignificant relationship between board gender diversity and corporate sustainability performance. Hence, H1, which states that a greater number of women on the board enhance sustainability performance, is not supported. This result is contradictory to previous research, which has shown a positive link between board gender diversity and corporate sustainability performance (Harjoto et al., 2015; McGuinness et al., 2017; Velte et al., 2016). However, there are several prior studies that can lend support to this insignificant finding (Ben Barka \& Dardour, 2015; Joseph, 2012; Muttakin, Khan, \& Subramaniam, 2015). For example, Ben Barka and Dardour (2015), in 2010, conducted a survey on 255 directors on the boards of 20 French listed firms and found that gender does not appear to be a significant parameter for enhancing corporate sustainability performance.

In the context of Bangladesh, typically, Bangladeshi corporate boards are male-dominated and most women are picked on the basis of family connections (Muttakin et al., 2015). These women could be seen as "tokens" to the expectations of society regarding women's inclusion on the board or of major stakeholders, and, therefore, can be ignored and not taken seriously, which could hamper their success as well as that of the whole board (Rahman \& Saima, 2018; Sultana et al., 2018). This argument can be further explained by the role congruity theory plays (Isaksson \& Steimle, 2009), where, due to prejudice towards female members, female members tend to get lower status positions than those of their male counterparts in the boardroom. Notably, Muttakin et al. (2015) found a significant negative result while examining women directors' influence on CSR performance from the Bangladesh context. Two possible arguments can be explained for this finding. Firstly, in Bangladeshi firms, women who are board members may lack education and expertise. Second, these female board members are mostly appointed on the basis of family ties. This suggests that female members who are named to boards based on family ties to ensure family supremacy in decisionmaking are unlikely to be worried about CSR issues (Muttakin et al., 2015; Rahman \& Saima, 2018).

The other important finding of the study is that it finds support for the mediation effect of ERM use on the relationship between board gender diversity and CSP (H2). More specifically, the effect of board gender diversity on corporate sustainability performance is fully mediated through ERM use. It is mentioned in the previous section that gender diversity is perceived as an indicator of an effective board. Moreover, even the most effective boards of directors are not in a position to manage and operate the day-to-day activities of the company for sustainability performance, rather they oversee strategic issues, which may contribute or risk the firm's overall performance. However, more and more scholars argue that the directors are responsible for helping to mitigate risk (Lenssen et al., 2014; Meulbroek, 2002). ERM increases the risk profile of an organization that can demonstrate its commitment to risk management (Meulbroek, 2002). In addition, the use of ERM can raise awareness of the risks in a company and thus improve the ability of decision-makers to optimize their value (Razali, Yazid, \& Tahir, 2011).

Moreover, the direct relationship between board gender diversity and sustainability performance has yielded mixed results (McGuinness et al., 2017; Muttakin et al., 2015; Velte et al., 2016). Thus, the inconsistencies in prior study results lead to the examination of ERM use as a new potential mediator to explain the relationship between board gender diversity and CSP performance. Some studies have lent 
support for ERM use as a mediator. For example, Crutzen and Herzig (2013) observed the emergence of new forms of accounting and control for sustainability that can support the strategic integration of sustainability into organizations. Likewise, after examining 174 publicly-listed companies in Malaysia, Soltanizadeh et al. (2016) notice that ERM mediates the relationship between business strategy and organizational performance. Moreover, due to the lack of direct control over firm sustainability performance, an effective board (with greater gender diversity on the boardroom) needs the assistance of the ERM framework to ensure holistic control over the firm's overall risk appetite and management. Effective risk management, in turn, contributes to the sustainability performance of a firm. This argument is also in tandem with this study's findings that board gender diversity influences the use of ERM and that ERM use influences sustainability performance. Thereafter, the mediating role of ERM use on board gender diversity and sustainability performance is reasonably supported.

This study provides some theoretical and practical implications. Apart from looking into the direct link between board gender diversity and CSP, this study also examined the mediation effect of ERM. Most previous studies that examined the relationship between board gender diversity and sustainability performance only focused on their direct relation and ignored the indirect path. Therefore, traditional studies have put all their effort into examining the direct relationship, which resulted in a mixed outcome. It is argued that these inconsistent results are due to not considering some other variable that can mediate this relationship. It is widely accepted that the board of directors rarely has a direct influence on its performance (COSO, 2004; Fakir, Jusoh, \& Rahin, 2019), and, consistent with the assumption, this study also finds support for the mediation role of ERM use. This means the board can influence sustainability performance by ensuring greater use of ERM in a firm. According to the study literature review, this indirect view of the board gender diversity and CSP relationship is not examined in any previous study. Thus, this study is capable of shedding some light on the other way of looking at the aforementioned relationship by introducing the mediation role of ERM use.

Finally, the paper focuses on the issue in the Bangladesh context. Bangladesh is one of the most promising developing countries and has shown its commitment to sustainability and good governance throughout the last decades (Nathalie, 2018). The pursuit of sustainable development is a constitutional obligation in Bangladesh (refer to Article 18A in the Constitution of the People's Republic of Bangladesh). Moreover, Bangladesh met all three eligibility requirements of the United Nations for graduation from the list of least developed countries (LDC) for the first time and is on track for graduation in 2024, while having already achieved several sustainable development goals (SDGs). Most sustainably studies relating to board gender diversity are carried out in the underdeveloped country context. Unlike a developed country, developing countries feature less demand for gender diversity or structured corporate governance. Moreover, the difference in culture and institutional environment opens a new window to see how this relationship exists. This paper fills this important research gap.

The analysis can provide useful guidelines for internal and external stakeholders of an organization in relation to realistic contributions, which will help top management explain the sustainability objective of the company and can guide them to a suitable structure. Managers could also use this study to better create and manage sustainability and choose the appropriate internal control structure to support success in sustainability. The judgment on sustainability investments can be of great use for investors. Regulatory bodies (e.g. Government, Securities and Exchange Commission) can also benefit from this report, devise more relevant and unique recommendations, and, eventually, enforce them in order to ensure that business efficiency is sustainably maintained.

\section{Conclusion}

Corporate sustainability is a multifaceted concept which is becoming increasingly relevant to modern business performance evaluation. Today's business is more complex; the demand for good governance is also growing, hence corporate governance is extremely relevant to the sustainability of the firm. In effect, there are very few studies that focus on corporate governance, in general, and board of directors, in particular, in relation to CSP (Fakir et al., 2019). In connection with the increasing demand for sustainability incorporation and the good governance of companies, this study examines the relationship between these two contrasting but objectively aligned disciplines of corporate sustainability and board gender diversity. Therefore, the study explored the interesting question concerning whether board gender diversity influences sustainability performance. Moreover, the study addressed the question whether the level of use of ERM is influenced by female board members and can ERM use further influence sustainability performance with a deeper look into the mediating effect in their (board gender diversity and sustainability performance) relationship.

The study obtained results after analysing data from a sample of Bangladeshi publicly-listed companies as a representation of a developing country context. It is suggested that female board representation does not tell much about sustainability performance in the case of the Bangladesh context. The study indicated a few reasons, most of which are country specific. Furthermore, the study finds strong support for the mediating role of ERM use within the corporate structure. Further analysis of the indirect effect 
suggests that ERM use mediates the relationship of board gender diversity and sustainability performance in full. This implies that, in the Bangladesh context, effective use of ERM is highly recommended. These results are empirically and theoretically supported, for example, contingency theory supports the effective use of ERM in line with pressure from the board of directors and other stakeholders, which, later, can influence performance. In fact, such an intervention in Bangladesh could be beneficial for other developing nations with similar political, economic, and cultural backgrounds, such as the countries of South-East Asia.

However, a generalization of these results is quite challenging as the study uses a cross-sectional self-rated survey questionnaire, and a few concepts of the study are overly dynamic and context specific. Therefore, future studies can explore causality and interrelations among other factors that are pivotal to board gender diversity and sustainability performance considering longitudinal data from the international sample. The study finds evidence for the mediation role of ERM use. There may be other variables that might also mediate board gender diversity and sustainability performance, for example, MCS use. Further studies can also examine the effect of the other sorts of board diversity in relation to sustainability performance, for example, board age, generational, and ethnic diversity, which are of interest to many scholars.

\section{References}

Ai, J., Brockett, P. L., Cooper, W. W., \& Golden, L. L. (2012). Enterprise risk management through strategic allocation of capital. Journal of Risk and Insurance, 79(1), 29-56.

Andriosopoulos, K. (2016). Energy security in East Asia under climate mitigation scenarios in the 21 st century. Omega, 59, 60-71.

Arfken, D. E., Bellar, S. L., \& Helms, M. M. (2004). The ultimate glass ceiling revisited: The presence of women on corporate boards. Journal of Business Ethics, 50(2), 177-186.

Artiach, T., Lee, D., Nelson, D., \& Walker, J. (2010). The determinants of corporate sustainability performance. Accounting \& Finance, 50(1), 31-51. doi:10.1111/j.1467629X.2009.00315.x

Bansal, P. (2005). Evolving sustainably: a longitudinal study of corporate sustainable development. Strategic Management Journal, 26(3), 197-218. doi:10.1002/smj.441

Baron, R. M., \& Kenny, D. A. (1986). The moderator-mediator variable distinction in social psychological research: Conceptual, strategic, and statistical considerations. Journal of personality and social psychology, 51(6), 1173.

Ben Barka, H., \& Dardour, A. (2015). Investigating the relationship between director's profile, board interlocks and corporate social responsibility. Management Decision, 53(3), 553-570.
Brown, S., \& Hillegeist, S. A. (2007). How disclosure quality affects the level of information asymmetry. Review of Accounting Studies, 12(2-3), 443-477.

Campbell, K., \& Mínguez-Vera, A. (2008). Gender diversity in the boardroom and firm financial performance. Journal of business ethics, 83(3), 435-451.

Carter, D. A., Simkins, B. J., \& Simpson, W. G. (2003). Corporate governance, board diversity, and firm value. Financial review, 38(1), 33-53.

Chih, H.-L., Chih, H.-H., \& Chen, T.-Y. (2010). On the determinants of corporate social responsibility: International evidence on the financial industry. Journal of Business Ethics, 93(1), 115-135.

Chin, W. W., Marcolin, B. L., \& Newsted, P. R. (2003). A partial least squares latent variable modeling approach for measuring interaction effects: Results from a Monte Carlo simulation study and an electronic-mail emotion/adoption study. Information systems research, 14(2), 189-217.

Cohen, J. (1988). Statistical power analysis for the behavioral sciences (2nd ed.) Hillsdale, MI: Erlbaum Associates.

COSO. (2004). Enterprise risk management: integrated framework. Durham, NC, USA: Committee of Sponsoring Organizations of Treadway Commission.

Crutzen, N., \& Herzig, C. (2013). A review of the empirical research in management control, strategy and sustainability. Studies in managerial and financial accounting, 26, 165-195.

Daily, C. M., \& Dalton, D. R. (2003). Women in the boardroom: A business imperative. Journal of Business strategy, 24(5), 8-10. doi:10.1108/jbs.2003.28824eaf.002.

De Cabo, R. M., Gimeno, R., \& Nieto, M. J. (2012). Gender diversity on European banks' boards of directors. Journal of Business Ethics, 109(2), 145-162.

Dess, G. G., \& Robinson, R. B. (1984). Measuring organizational performance in the absence of objective measures: the case of the privately-held firm and conglomerate business unit. Strategic management journal, 5(3), 265-273.

Eisenberg, M. A. (1997). The board of directors and internal control. Cardozo L. Rev., 19, 237-264.

Fakir, A. N. M. A., Jusoh, R., \& Rahin, N. M. (2019). Board of directors' characteristics, internal control mechanisms and corporate sustainability performance: a theoretical framework. World Review of Entrepreneurship, Management and Sustainable Development, 15(6), 765-784.

Fama, E. F., \& Jensen, M. C. (1983). Agency problems and residual claims. The journal of law \& Economics, 26(2), 327-349.

Fornell, C., \& Larcker, D. F. (1981). Evaluating structural equation models with unobservable variables and measurement error. Journal of marketing research, 18(1), 39-50.

Garver, M. S., \& Mentzer, J. T. (1999). Logistics research methods: employing structural equation modeling to test for construct validity. Journal of business logistics, 20(1), 33-57. 
George, G. (2005). Slack resources and the performance of privately held firms. Academy of management Journal, 48(4), 661-676.

Gordon, L. A., Loeb, M. P., \& Tseng, C.-Y. (2009). Enterprise risk management and firm performance: A contingency perspective. Journal of Accounting and Public Policy, 28(4), 301-327.

Hair Jr, J. F., Hult, G. T. M., Ringle, C., \& Sarstedt, M. (2017). A primer on partial least squares structural equation modeling (PLS-SEM). Thousand Oaks, CA: Sage Publications.

Harjoto, M., Laksmana, I., \& Lee, R. (2015). Board diversity and corporate social responsibility. Journal of Business Ethics, 132(4), 641-660.

Harman, H. H. (1976). Modern factor analysis (3rd ed.). Princeton, New Jersey, USA: University of Chicago press.

Hayes, A. F. (2017). Introduction to mediation, moderation, and conditional process analysis methodology: a regression-based approach.New York, NY: Guilford Press.

Hillman, A. J., Shropshire, C., \& Cannella, A. A. (2007). Organizational predictors of women on corporate boards. Academy of Management Journal, 50(4), 941-952.

Huang, Y. S., \& Wang, C.-J. (2015). Corporate governance and risktaking of Chinese firms: The role of board size. International Review of Economics \& Finance, 37(3), 96-113.

Isaksson, R., \& Steimle, U. (2009). What does GRI-reporting tell us about corporate sustainability? The TQM Journal, 21(2), 168181.

Joseph, G. (2012). Ambiguous but tethered: An accounting basis for sustainability reporting. Critical perspectives on Accounting, 23(2), 93-106.

Lawrence, P. R., \& Lorsch, J. W. (1967). Differentiation and integration in complex organizations. Administrative science quarterly, 12(1), 1-47.

Lenssen, G., Nijhof, A., Roger, L., Kievit, H., Lenssen, J.-J., A. Dentchev, N., \& Roger, L. (2014). Sustainability, risk management and governance: towards an integrative approach. Corporate Governance, 14(5), 670-684.

Lourenço, I. C., \& Branco, M. C. (2013). Determinants of corporate sustainability performance in emerging markets: the Brazilian case. Journal of Cleaner Production, 57, 134-141.

McGuinness, P. B., Vieito, J. P., \& Wang, M. (2017). The role of board gender and foreign ownership in the CSR performance of Chinese listed firms. Journal of Corporate Finance, 42, 75-99. doi:10.1016/j.jcorpfin.2016.11.001

Meulbroek, L. K. (2002). Integrated risk management for the firm: a senior manager's guide. Journal of Applied Corporate Finance, 14(4), 56-70.

Moeller, R. R. (2007). COSO enterprise risk management: understanding the new integrated ERM framework. New York, NY: John Wiley \& Sons Inc.

Muttakin, M. B., Khan, A., \& Subramaniam, N. (2015). Firm characteristics, board diversity and corporate social responsibility: Evidence from Bangladesh. Pacific Accounting Review, 27(3), 353-372.

Napitupulu, S., Primiana, I., Nidar, S. R., Effendy, N., \& Puspitasari, D. M. (2020). The Effect of Management Capabilities in Implementing Good Corporate Governance: A Study from Indonesia Banking Sector. Journal of Asian Finance, Economics and Business, 7(1), 159-165. https://doi. org/10.13106/jafeb.2020.vol7.no1.159

Nathalie, R. (2018). Bangladesh, UN Consider Expected LDC Graduation in 2024. The SDG Knowledge Hub, 18 December 2018, Winnipeg, Manitoba, Canada.

Parker, H., \& Ameen, K. (2017). The role of resilience capabilities in shaping how firms respond to disruptions. Journal of Business Research, 88(6), 535-541.

Pfeffer, J., \& Salancik, G. R. (1978). The external control of organizations: A resource dependence perspective. New York, NY: Harper and Row Publishers.

Podsakoff, P. M., MacKenzie, S. B., Lee, J.-Y., \& Podsakoff, N. P. (2003). Common method biases in behavioral research: A critical review of the literature and recommended remedies. Journal of Applied Psychology, 88(5), 879-903.

Preacher, K. J., \& Hayes, A. F. (2008). Contemporary approaches to assessing mediation in communication research. In A. F. Hayes, M. D. Slater, \& L. B. Snyder (Eds.), The Sage sourcebook of advanced data analysis methods for communication research (p. 13-54). Sage Publications, Inc. https://doi. org/10.4135/9781452272054.n2

Provan, K. G. (1980). Recognizing, measuring, and interpreting the potential/enacted power distinction in organizational research. Academy of Management Review, 5(4), 549-559.

PwC. (2018). Annual Corporate Directors Survey, October 2018. London, UK: PricewaterhouseCoopers.

Rahdari, A. H., \& Rostamy, A. A. A. (2015). Designing a general set of sustainability indicators at the corporate level. Journal of Cleaner Production, 108, 757-771.

Rahman, M. M., \& Saima, F. N. (2018). Efficiency of Board Composition on Firm Performance: Empirical Evidence from listed Manufacturing Firms of Bangladesh. Journal of Asian Finance, Economics and Business, 5(2), 53-61. https://doi. org/10.13106/jafeb.2018.vol5.no2.53

Rao, K., \& Tilt, C. (2016). Board composition and corporate social responsibility: The role of diversity, gender, strategy and decision making. Journal of Business Ethics, 138(2), 327-347.

Razali, A. R., Yazid, A. S., \& Tahir, I. M. (2011). The determinants of enterprise risk management (ERM) practices in Malaysian public listed companies. Journal of Social and Development Sciences, 1(5), 202-207.

Ringle, C., Wende, S., \& Will, A. (2005). Smart-PLS Version 2.0 M3. University of Hamburg.

Sharma, S., \& Henriques, I. (2005). Stakeholder influences on sustainability practices in the Canadian forest products industry. Strategic management journal, 26(2), 159-180. 
Sila, V., Gonzalez, A., \& Hagendorff, J. (2016). Women on board: Does boardroom gender diversity affect firm risk? Journal of Corporate Finance, 36, 26-53. doi:10.1016/j. jcorpfin.2015.10.003

Simsek, Z. (2007). CEO tenure and organizational performance: An intervening model. Strategic Management Journal, 28(6), 653-662.

Soltanizadeh, S., Soltanizadeh, S., Abdul Rasid, S. Z., Abdul Rasid, S. Z., Mottaghi Golshan, N., Mottaghi Golshan, N., . . . Wan Ismail, W. K. (2016). Business strategy, enterprise risk management and organizational performance. Management Research Review, 39(9), 1016-1033.

SSGA. (2018). Fearless Girl's Impact: More than 300 Companies Have Added Female Directors. Boston, MA: State Street Global Advisors.

Sultana, S., Zulkifli, N., \& Zainal, D. (2018). Environmental, Social and Governance (ESG) and Investment Decision in Bangladesh. Sustainability, 10(6), 1-19.

Tahir, H., Rahman, M., \& Masri, R. (2020). Do Board Traits Influence Firms' Dividend Payout Policy? Evidence from Malaysia. Journal of Asian Finance, Economics and Business, 7(3), 87-99. https://doi.org/10.13106/jafeb.2020.vol7.no3.87

Talke, K., Salomo, S., \& Rost, K. (2010). How top management team diversity affects innovativeness and performance via the strategic choice to focus on innovation fields. Research Policy, 39(7), 907-918.

Torugsa, N. A., O’Donohue, W., \& Hecker, R. (2012). Capabilities, proactive CSR and financial performance in SMEs: Empirical evidence from an Australian manufacturing industry sector. Journal of Business Ethics, 109(4), 483-500.

Vanguard. (2017). An open letter to directors of public companies worldwide. Washington, USA: Vanguard Publishing.

Velte, P., Jones, G., \& Jones, G. (2016). Women on management board and ESG performance. Journal of Global Responsibility, 7(1), 98-109.

Wang, J., \& Coffey, B. S. (1992). Board composition and corporate philanthropy. Journal of business Ethics, 11(10), 771-778.

Wernerfelt, B. (1984). A resource-based view of the firm. Strategic management journal, 5(2), 171-180.

Williams, R. J. (2003). Women on corporate boards of directors and their influence on corporate philanthropy. Journal of Business Ethics, 42(1), 1-10.

Yilmaz, A. K., \& Flouris, T. (2010). Managing corporate sustainability: Risk management process based perspective. African journal of business management, 4(2), 162-171.

Zhao, X., Lynch, J. G., \& Chen, Q. (2010). Reconsidering Baron and Kenny: Myths and Truths about Mediation Analysis. Journal of Consumer Research, 37(2), 197-206. doi:10.1086/651257 